Article

\title{
The Educational Sociology and Political Theology of Disenchantment: From the Secularization to the Securitization of the Sacred
}

\author{
Liam Gearon \\ Department of Education, University of Oxford, 15 Norham Gardens, Oxford OX2 6PY, UK; \\ liam.gearon@education.ox.ac.uk
}

Received: 1 December 2018; Accepted: 18 December 2018; Published: 27 December 2018

\begin{abstract}
This article provides an outline theoretical synthesis of educational sociological and political theology, through the concept of 'disenchantment' to afford insights on critical current debates around secularization and securitization. Drawing together two originating frameworks-Max Weber's (1918) sociological theorization of religious authority's intellectual demise as disenchantment of the modern world and Carl Schmitt's (1922) contemporaneous framing of a political theology-this article argues that a bringing together of these apparently disparate perspectives facilitates an understanding of securitization as a staging post in the history of the secularization of religion in education. Here an educational sociology and political theology of disenchantment thereby provides embryonic evidence of the securitization of the sacred as a staging post in the history of secularization. It is argued, in conclusion, that all these framings are a matter of decision-making in the exercise of ideological, political and theological power in and through education. Such decision-making in educational policy presents new sociological and political-theological territory for empirical and theoretical analysis of the shifting sources of authority amongst what C. Wright Mills called the "power elite".
\end{abstract}

Keywords: security; secularization; securitization; enchantment; Weber; Schmitt

\section{Introduction}

At Munich University in 1918 the sociologist Max Weber delivered a lecture entitled 'Science as a Vocation' (Weber 2015). Here he famously defined the consequences of increased intellectualization, rationalization and technologization as a 'disenchantment' of the modern world. Weber's metaphor has had resonances across the century which followed, particularly influencing sociological theory and research on secularization, the standard framings of which have seemingly been challenged by the apparent resurgence of religion in global governance (for example, Carroll 2009; Ghosh 2014; Hughey 1979; for a literature review on secularization, see Pollack 2013).

The same post-First World War period also saw publication, in 1922, of Schmitt (2005) Political Theology, delineating the transference of theological influence to political power in the governance of States (Hollerich 2011). Evermore rehabilitated from his associations with Nazism, a still controversial and yet in large measure rehabilitated Schmitt (Hollerich 2011) has come of late to be drawn upon as a theorist of law and international governance, providing significant new analyses on sovereignty and authority in and for contemporary politics (Kahn 2012), and critically important insights on the role of religion in the modern world (Koskenniemi 2006; Emden 2006, gives a most valuable contextualization of Schmitt from the Weimar Republic to the Third Reich) (see also Hohendal 2008). Schmitt's originating conceptualization of 'political theology' has been equally influential in framing modern-day relations between religion and politics, one which has been acutely relevant to contexts of global governance which seem to show a resurgence of religious authority in global political power, 
especially in arenas of security, terror and war, and which have been in turn used to provide real world exemplars to challenge theories of secularization (for an authoritative review of Carl's Schmitt's multi-disciplinary influences, see Vinx 2014).

I provide an outline theoretical synthesis of educational sociological and political theology through the concept of 'disenchantment' to afford insights on critical current debates around secularization and securitization. Drawing together two originating frameworks-Weber (2015) sociological theorization of religious authority's intellectual demise as disenchantment of the modern world and Schmitt (2005) contemporaneous framing of a political theology-I argue that a bringing together of these apparently disparate perspectives facilitates an understanding of securitization as a staging post in the history of the secularization of religion. Nascent indications of a complex interplay of ideology and theology, it is argued, are currently emergent as an empirical, that is, sociologically, demonstrable process evident in patterns of global policy development for religion in education. An educational sociology and political theology of disenchantment thereby provides embryonic evidence of the securitization of the sacred as a staging post in the history of secularization.

It is argued, in conclusion, that all these framings are a matter of decision-making in the exercise of ideological, political and theological power in and through education. Such decision-making in educational policy presents new sociological and political-theological territory for empirical and theoretical analysis of the shifting sources of authority amongst what $C$. Wright Mills called the 'power elites' (on the sociology of elites, see also Hartmann 2007). Indeed, interestingly, the link between C. Wright Mills and Weber is historically strong. It was Gerth and Wright Mills who translated and edited From Max Weber: Essays in Sociology in 1946 and brought Weber's now famous characterization to a wider audience.

\section{The Educational Sociology and Political Theology of Disenchantment}

In 2018, one hundred years after the Munich lecture, we recall Weber's words:

The increasing intellectualisation and rationalisation do not, therefore, indicate an increased and general knowledge of the conditions under which one lives. It means something else, namely, the knowledge or belief that if one but wished one could learn it at any time. Hence, it means that principally there are no mysterious incalculable forces that come into play, but rather that one can, in principle, master all things by calculation. This means that the world is disenchanted. One need no longer have recourse to magical means in order to master or implore the spirits ... for whom such mysterious powers existed. Technical means and calculations perform the service. This above all is what intellectualization means. (Weber 1946, p. 7)

Delivered at the close of the First World War, Weber is speaking at the imminent collapse of German imperial hopes. The mass slaughter of the trenches, what Wyschogrod (1990) what later call 'man-made mass death', was also an early nail in the coffin of Enlightenment optimism. This one terrible chapter in the history of war is important for understanding the deeper sense of Weber's sense of disenchantment: the dawning disillusion with Enlightenment reason, scientific revolution, and human progress through technologization. Religion's displacement proved a poor source of hope.

Here was a then revered sociologist who had done much to evoke fresh insights on religion and the rise of capitalism. Weber went against much characterization of religion as reactionary, anti-progressive, politically retrogressive, and intellectually obscurantist. Thomas Paine's 1791/2 Rights of Man (Paine 2008) for example, like many Enlightenment contemporaries, saw rejection of religion as part of the inevitable path to ideological and political maturity:

In casting our eyes over the world, it is extremely easy to distinguish the governments which have arisen out of society or out of the social compact, from those which have not; but to place this in a clearer light than what a single glance may afford, it will be proper to take a review of the several sources from which governments have arisen, and on which they 
have been founded. They may be all comprehended under three heads. First, Superstition. Secondly, Power. Thirdly, The common interest of society, and the common rights of man. (Paine 2008, p. 120)

In politics as in philosophy, Kant's Critique of Pure Reason had rid philosophy of its transcendent referents. Prefiguring and shaping Weber's thought Kant (1784) made a defining and famously concise assertion of rationality (Weber's intellectualization) over religion:

Enlightenment is man's emergence from his self-imposed nonage. Nonage is the inability to use one's own understanding without another's guidance. This nonage is self-imposed if its cause lies not in lack of understanding but in indecision and lack of courage to use one's own mind without another's guidance. Dare to know! ... 'Have the courage to use your own understanding', is therefore the motto of the enlightenment. (Kant 1784, np)

Individual autonomy was integral to Enlightenment. Ridding the self of religious delusion was the path to freedom from political and psychic bondage.

Feuerbach's 1840 The Essence of Christianity thus castigated religion as simply wish fulfillment (Feuerbach 1989). Variant interpretations of religion as psychic projection were adopted by Marx, by'Freud, by Durkheim (Pals 2014). In the sciences of the age, all epistemological credibility depended upon the critique of religion to authoritative knowledge. No one really puts this view better than Marx's 1843 statement that: 'the critique of religion is the prerequisite of all critique' (Marx 2009). To be clear: through Comte, Condorcet to Durkheim and Weber, all classical sociology is in its origins the sociology of disenchantment. Weber's disenchantment is thus a statement of consequence. Religious is displaced, by: philosophical reason, political rationality, technologization, world war. It was not exactly a happy time, less the flowering of Enlightenment optimism than its death-knell.

Yet the experiment continued. Arendt (2004), Berlin (2002), Hayek (2001), Hobsbawm (1995), Popper (2011), Talmon (1961) were all important contemporary commentators as it did. As Hayek (2001) would comment on in 1944, in an age of political extremes, liberalism—or freedom-seeking epistemologies and socio-political systems-not only would the experiment take increasingly socialistic forms but much of their form would be shaped by intellectuals. One year from the October Revolution, from his lectern at Munich Weber would look west to the trenches of France and Flanders but also east to Moscow and St Petersburg. As Revolution and Civil War in Russia would move ultimately to Leninist and Stalinist victory, other forces were gathering at Enlightenment's wake. In 1922, a German legal theorist, Schmitt (2005) wrote a defining text about the political search for total power. He called the book Political Theology. It was sub-titled Four Chapters on the Concept of Sovereignty. The central idea of relevance here is Schmitt's delineation of a centuries-long transference of theological influence to political power in the governance of States, justifying States' exercise of extreme, liberty denying power in exceptional times. Exceptional times were indeed ahead. And for this reason, the Nazi-sympathizing Carl Schmitt became a fashionable intellectual adjunct of legally justified totalitarianism in Germany.

The anticipated future of religion was-in the diminishing sphere of religious authority-the same in all cases. In the Treatise on General Sociology (Pareto 1963), Pareto, the 'Karl Marx of Fascism', saw religion as a spent remnant of past hierarchical dominance, replaced with nationalistic, and militaristic, might (Alexander 1994). As with Schmitt, a theological reinterpretation of the political as a form of religion became common. Its antecedence is found in Rousseau's notional 'civil religion'. Its manifestation in social form reaches its apogee in 'totalitarianism'. A term framed by Gentile, Mussolini's philosopher, as a state of 'total power', political power replacing theological authority is a theme in much literature on totalitarianism (Friedrich and Brzezinski 1967). Here 'totalizing' political structures replace the old theological order to form what Voegelin in the 1930s described as the new 'political religions' (Maier 2004, 2007; Maier and Schafer 2007; Voegelin 1999).

New intellectual and political horizons came thereby to dominate the socio-political and intellectual landscape. Inevitably this involved complex institutional as well as intellectual transferences of authority and power, the creation of new socio-political and intellectual elites. 
The intellectual milieu of Weber's sociology of disenchantment and Schmitt's political theology are capable of here providing originating insights on this shifting moment in the history of ideas. These are the moments, still observable today, when new epistemological currencies find new socio-political form. In the pervasive loss of religious influence through such processes (bureaucratization, intellectualization, technologization), which Weber described, a new sociological of elites, or a sociology of the new elites, was de facto formed. Understood in these terms, sociologically, disenchantment was therefore in essence, and so remains, in complex ways, a displacement of epistemological and political-theological referents. Society manifests these displacements in religious terms through a declining influence of the theological. This process is most often called secularization. I want to suggest here that modern cases of religions entanglements are evidence not of a counter-secularization but rather a staging post in the sociological history of secularization.

\section{Secularization and Securitization}

Secularization theory appears in many variant forms. It can be defined broadly as a marginalization of religion from public and particularly political life, or as Peter Berger once put it, 'the process by which sectors of society and culture are removed from the domination of religious institutions and symbols' (Berger 1967, p. 107). Remnants of such religious institutions and symbols appear in and through religious educational goals of social and community cohesion. This allows and continues to enable religion to serve a sociological purpose. Even Kant was happy for religion to persist, if stripped of transcendent reference, to facilitate a social and community cohesiveness. This was Kant's 'religion within the bounds of reason'. John Dewey, the still today influential American philosopher of education was also content to see a 'religion of humanity'. The echoes of Rousseau's hopes in (and integral to) the Social Contract similarly give religion political status by the determination of 'civil religion', later powerfully echoed by the American sociologist Robert Bellah. Berger (1970) later made a further claim that modern consciousness is itself defined by secularization. Taylor (2007) has similarly suggested that 'the real significance of secularism is not the containment of belief to the private sphere ... or the decline in belief itself ... but a shift in the conditions of belief which have made unbelief viable ... ' (Taylor 2007). We recognize that such modern consciousness is shaped by many forces, and high upon the chart of influence must rank education. This would all appear to be a triumph for Enlightenment expectations. In many senses it is, and we may note too, that some of such triumphs are subtle, as in apparently neutral treatments of religion in education.

The process is literally not straightforward. Warner (1993) is one social theorist who challenged linear models of secularization held in variant form by Robert Bellah, Richard Fenn, Thomas Luckmann, David Martin, Talcott Parsons, Bryan Wilson, Richard Fenn, and, until a sociological volte face, by Peter Berger himself. Warner distinguishes the 'old' and 'new' paradigms of secularization by giving more credence to a more 'dialectical' model which resists easy models of historical progression. Goldstein $(1999,2009)$ challenges aspects of Warner's view - the latter does not fully account the notion of linear and fails to recognize the dialectical nature of the old paradigm-but Goldstein concurs that secularization is still valid, we just have to recognize that its progression is fitful and halting.

The sociology of secularization is itself messy, as so often sociology itself is messy. As Hans-Georg Gadamer would have it, the world examined by the social sciences, the 'sociohistorical world', is replete with more variables than the laws sought in the natural sciences, and, consequently, social theorists need rather 'to understand the phenomenon itself in its unique and historical concreteness' (Gadamer 2004, p. 4). Sometimes, with religion and its sceptics, there is give and take. Illustrative of such is Jürgen Habermas and Cardinal Joseph Ratzinger's (later Pope Benedict XVI) public discussions of 'the dialectics of secularization', an interchange between Enlightenment reason and traditional Christian thought, and what Victor Turner might phrase as the liminal intellectual and social space both inhabit (Habermas and Ratzinger 2007; see also Habermas 2008, his 'notes' on a 'post-secular' society).

We can note that once ardent adherents of secularization have themselves recanted their former faith. We compare Berger's 1967 The Sacred Canopy (Berger 1967; also Berger 1970) with The 
Desecularization of the World (Berger 1999), or Berger's latter-day collaborations with others skeptical of secularization theory (Davie et al. 2008). We can also note the persistence of diehard secularization theorists. For instance, Bruce (2002) God is Dead brings strong sociological evidence to give empirical life to the old Nietzschean adage. The retort that 'God is back' (Micklethwait and Wooldridge 2010) seems to go hand in hand with Stark's funerary oration for secularization theory, 'Secularization R.I.P' (Stark 1999).

Intense contemporary, socio-political interest in religion in public life here, then, pre-dates but cannot avoid the fulcrum point of 11 September 2001. Preeminent among pre-9/11 theorists of religion to challenge then normative expectations of secularization was Jose Casanova. Casanova (1994) Public Religions in the Modern World provided the socio-political groundwork for many revisionary accounts of secularization across the sociology of religion (see also Casanova 2009). Huntington (2002) post-Cold War Clash of Civilisations thus shared many of Casanova's assumptions, and 9/11 seemed to confirm that religion-whatever theoretical construct we chose-could still leave indelible marks on global governance.

In the present, the resurgence of religion in public life has been marked by debates centered on explaining such impacts on polity (Habermas 2006). These debates have often been framed as variant forms of political theology (De Vries and Sullivan 2006; Scott and Cavanaugh 2011). It is this latter political context which has given particular strength to the resurgence of political theology itself (for example, Scott and Cavanaugh 2011; De Vries and Sullivan 2006). Indeed, the entire field of religious studies and theology in universities, and school-level religious education, seems to have been injected with a strong dose of invigoration from the destruction of the Twin Towers and all the foreign policy and global terrorism alerts which have followed us down to the present-day.

As theorists in the sociology of religion, we may usefully return to Voegelin (1999) analysis of the 'political religions' (Maier 2004, 2007; Maier and Schafer 2007) or the enduring literature on autocracy, dictatorship and totalitarianism (Arendt 2004; Casanova 1994, 2009; Friedrich and Brzezinski 1967; Popper 2011; Talmon 1961). But to me, re-reading Schmitt (2005), I note once more his claim that 'All significant concepts of the modern theory of the state are secularized theological concepts' (Schmitt 2005, p. 36). Schmitt's assertion that the political is colonized theology seems to me to be still valid. We note with Gray $(2017$, p. 1) therefore, that 'Modern politics is a chapter in the history of religion.' It may seem that the political has today an added security dimension. Yet with total war at the heart of totalitarianism, security was indelibly prefigured in those histories discussed in relation to Schmitt, Pareto and Mosca.

In security and intelligence studies, theorists have long remarked on an expansive 'securitization' across numerous social domains (Albert and Buzan 2011; Dunn Cavelty and Balzacq 2017; Taureck 2006; Huysmans 1998). Securitization theory has possibilities here to view religion in public context from a new sociological lens, representing as it does a critical analytical frame of reference to securitization in five realms, beyond the military to the political, societal, economic, and environmental (Buzan et al. 1997; Huysmans 1998; Van Munster 2016). Prior to 9/11, Bagge Laustsen and Wæver (2000), perceptively added a sixth category, that of religion. As C. Wright Mills in The Power Elites intimated, new national security networks and operational structures are to be interpreted as adjuncts of political power, indeed security and intelligence agencies have in their histories-we may look at Weiner (2012) history of the CIA-been seen as independent of democratic polity and governance. Nominally at least in State control, the power inherent in such security and intelligence systems marked an intensification of State or secular over religious authority. In basic terms, religious authority is further subject to political power, in intensified ways. It is by such thinking we can see nascent correspondences between secularization and securitization.

\section{The Secularization and the Securitization of Religion in Education}

If, then, the public prominence of religion is a self-evident socio-political fact, newly intensified, post- $9 / 11$ security contexts have sharpened the already emergent observations about religion in the 
modern world (Casanova 1994; Davis et al. 2005; Dunn Cavelty and Balzacq 2017; Haynes 2008; Hovey and Phillips 2015; Schussler Fiorenza et al. 2013; Seiple et al. 2011). Such contexts have given political theology itself a new scholarly momentum (De Vries and Sullivan 2006; Scott and Cavanaugh 2011). For researchers in religious education this has too engendered renewed justifications for their endeavors, (Jackson 1997, 2011; Jackson et al. 2007; Weisse 2011; Jackson 2014).

Such a post-Cold War and post-9/11 geopolitical and political-theological milieu has revived high level debate around the roles of religion in global governance (Davis et al. 2005; Habermas 2006; Habermas and Ratzinger 2007; Haynes 2008, 2009; Schussler Fiorenza et al. 2013). Publicly funded education has, across Europe and indeed worldwide, has through program of learning about and from religion become a primary vector of pedagogically enabling the management of political-theological extremes. For any sociologist unfamiliar with the field of religion in education internationally, there is no better single source for exploring the range of variant forms of such treatments in different country contexts than Davis and Miroshnikova (2017) encyclopedic 64 case studies; these show how constitutional and legislative differences impact the detail of such processes but not the principles of political policy implemented in the classroom. For those interested in the legislative detail of how religion and law intertwine with education Hunter-Henin (2012) is also a good starting point, demonstrating how religion in education is framed by legislative structures to inculcate and maintain the production and sustaining of moderate (that is non-'extreme') personal and societal value.

In global context political processes effect such impact through a range of inter-governmental agencies: in the United Nations system the Special Rapporteur for Freedom of Religion or Belief plays here a critical role (UN 2018); in terms of broader cultural systems UNESCO $(2006,2011)$ has a multiple number of policy programs on democracy human rights and intercultural understanding effected through education. In European settings the Council of Europe benchmarks political principle through pedagogic practice in numerous ways (CoE 2008). Of late, as I have long noted, such political purposes served through pedagogical practices have developed a very specific and self-defined security function, and of paramount importance here is the otherwise perplexing engaging of a Cold War security agency in the teaching of religion in public schools-no lesser a body that is than the Organisation for Security and Cooperation in the Europe and its widely influential Toledo Guiding Principles on Teaching about Religions and Beliefs in Public Schools (OSCE 2007; Gearon 2017a, 2017b). The facts of powerful international political agencies responding to crises of global security through education-itself entirely understandable-is perhaps nowhere better illustrated, nor anywhere more directly, than in the UN's direct organizational response to a book and an academic thesis: here Huntington (2002) Clash of Civilizations prompted a post-Madrid bombing response with the creation of a very high level political initiative with global reach and education to the fore, namely the formation of counter-thesis to Huntington in the form of the Alliance of Civilizations (UNAoC 2018). In the simplest of terms, the role of religion in education is here to help maintain social and community cohesion (Jackson and O'Grady 2007) and to counter terrorist ideology and actions seemingly by religious belief and motivation (Gearon 2013; Gearon and Prud'homme 2018). My suggestions concerning a politicization and securitization of religion in education have here brought some startling defensive attacks. I am confident however in my analysis. Namely, that this political interest in religion and education has of late sharpened to security concerns with a wealth of counter-terrorist agendas being incorporated into frameworks for religion in education, prompting heated debate over 'the politicization and securitization of religion in education' (see author and opponents reviewed Gearon 2017a, 2017b).

Yet, there have also been some measured responses. Willaime (2007) argues, effectively to my mind, that the pattern of such religion in education are held on tract by a 'double constraint': 'a sociological one, in that the religious and philosophical pluralization of European societies obliges them to include ever more alternative religions and non-religious positions into their curricula, and a legal one, through the importance of the principle of non-discrimination on religious or philosophical grounds (as well as others such as gender or race) in international law, especially in the European 
Convention on Human Rights' (Willaime 2007, p. 65, emphasis in original). If we examine any international country setting, these 'constraints' show similar patterns of a complex nexus of religion, politics and education (Durham 2017; Ferrari 2017). The placing of religion in education now to security as an enhanced aspect of political purpose is here something new, and worth studying. Framed as part of elites' research methodology and theory, the examination of the powers behind the policy seems to me to be an even more pressing, not to say interesting avenue of exploration for sociological enquiry.

While, then, classic studies of the power behind educational institutions, social validations, epistemic control, and so forth are familiar to us through the work of Ball (2013); Bourdieu (1986); Foucault (1970, 1972, 1977, 1980, 2009, 2010) and Mills (2000), specific sociological focus on religion in education as an aspect of the power elite is less studied.

We may thus ask 'If God is back, on whose terms?' This question begs an answer which requires an analysis of the ideological sources of religion's perceived and actuated role in education. If longsustained and occasionally vilified have been my arguments that the new apparent relevance of religion in education can be characterized as a politicization and securitization (Jackson 2015), my argument would be if the defense is so strong then there may be something in the critique. Framing secularization as a shift of religious power to political authority (Chaves 1994; cf. Casanova 2009), I therefore re-state my position that for religion in education has achieved new pedagogical purposes as part of, as an adjunct of political and security discourse (Gearon 2013, 2017a).

Initially, then, high level political and security agendas of global governance may seem very distant from education. Yet closer inspection reveals that education, especially religion in education, is in fact one of the key interlocutors of the relationship between politics and security. Here, education is permeated ever more acutely with security themes, especially those aspects of education dedicated to countering terrorism, violent extremism and related anti-democratic ideologies (again, a useful research literature overview on counter-extremist education is Ghosh et al. 2016). Further accentuation of security agendas in education are evident in the UK Government's Counter Terrorism and Security Act 2015 which mandates public bodies such as schools and universities to legislative responsibilities for security. The European Agenda on Security (EAS 2015) too has drawn universities in particular to similar territory, recognizing knowledge generation in higher education as a site of security impacts, positive as well as in terms of threat. I have long characterized such movements as the 'counter-terrorist classroom' (Gearon 2013) and the 'counter-terrorist campus' (Gearon 2017c; Gearon 2018). In religion in education such exemplars represent what securitization theorists call a 'securitizing move' (for example, Taureck 2006).

I have suggested that securitization is itself a lesser commented on staging post in theories of secularization. Closer inspection may yet reveal further points of conceptual and operational nexus between the sociological debates around secularization and securitization theory. This is not to oversimplify the complexities of either secularization or securitization theory. The claims of educationalists are, however, that a certain reverse of secularization processes is currently taking place in the light of new political and security prominences of religion in global governance. For example, a lead researcher suggested of their pan-European project-'Religion in Education A contribution to dialogue or a factor of conflict in transforming societies of European Countries (REDCo)' - that, 'In most European countries, we have assumed for a long time that increasing secularization would lead to a gradual retreat of religion from public space. This tendency has reversed itself in the course of the past decade as religion has returned to public attention' (Weisse 2011, p. 112). To my mind, however, as I have noted elsewhere, this-and all related political framing for religion in education, as serving citizenship, human rights, social justice or advancing a 'civil religion' (Jackson and O'Grady 2007) -is nothing but a variant on Carl Schmitt's political theological theme, to re-state, that 'All significant concepts of the modern theory of the state are secularised theological concepts'. Religious education here represents the secularization of theological concepts as pedagogical practice.

I accept, as Lewin (2016, 2017a, 2017b) comments, following Habermas (2008) that all of this represents a 'complication of the secular' and a measure, as Vattimo has it, of a 'disenchantment with 
the very idea of disenchantment' (Vattimo 2003, p. 30). Yet political agendas nowhere meet pedagogical practice more powerfully than in the explicit conjuring up of 'civil religion' as a determining frame for the political uses of religion in education (Jackson and O'Grady 2007; cf. Rousseau 1968; Bellah 1967). Where I have shown this politicization of religion in education becoming more integrated with security agendas I conceptualize this as the 'securitization of religion in education' (Gearon 2013, 2017a, 2017b). This has brought support as well as strong opposition (Jackson 2015; Newell 2015).

My work on religion in education has, however, in Weberian terms, a far wider focus than and securitization. It has been preoccupied with determining the epistemological and ideological origins of religious educational policy by tracing its etiological roots. My work holds a central thesis: once religious education is separated from the religious life-where education in plural societies can no longer subscribe to nurture within a particular tradition-religious education requires alternative grounds. The search for new epistemological grounds is the inevitable consequence of the separation of religious education from the religious life. Ironically, the grounds sought are in those very Enlightenment traditions which have provided the most powerful critiques of religion. The solution has lain or has been sought in the seeking of new-critically distancing-epistemological and pedagogical foundations for religious education. The principles of a critical study of religion-Weber's 'intellectualization' - are central to worldwide religious education (Davis and Miroshnikova 2017).

Noting the 1918 centenary of Max Weber's Science as a Vocation', particularly Weber's idea of the 'disenchantment of the modern world', the epistemologies of contemporary religious education are part of a broader sociology of disenchantment. A hundred years after Weber's lecture, the problematics of religion in contemporary education are integral and run parallel to the problematics of modern sociology of religion, to theories of secularization and counter-secularization, to the politicization and even securitization of religion. Schmitt is useful here. Where Weber details the general and modern intellectual and indeed specifically educational situation - he is after all talking about science as a vocation, and interestingly using a religious metaphor of vocation (in all other prior context used as a call to the religious life), no doubt intentionally. Schmitt here allows us to penetrate beneath the surface of the modern political to its theological antecedents. But he does more. The notional idea of vocation shows the secularizing impact of shifting intellectual landscape where the call of science loudly overrides the outdated claims of the sacred.

I have identified a similar pattern of overriding voices in religious education, much as Weber intimates how intellectualization defines the criticality of modern consciousness. It has been charged in often said vituperative debates that I am opposed thereby to the critical study of religion (Various references). This is not true. I point merely to the epistemological origins and impacts of this criticality. A sympathetic critic has summarized my examination of the post-Enlightenment epistemological foundations of religion in education as follows:

Each of the disciplines-psychology, politics, phenomenology and aesthetics, but also natural sciences, social sciences, and philosophy, seven in total—understand religion and religious education in a purely immanent account of knowledge. Thus each reduces religion and religious education to its own lowest common denominator. Secularity's pretended neutrality masks a definite agenda which appears in different guises, conditioned by the history of the respective discipline. (Newell 2015, p. 235)

As this same reviewer further and correctly suggests:

If religious education is a political and epistemological captive of modernity, how much more is public education and public knowledge pressed into service. (Newell 2015, p. 236)

As Aldridge (2015) also intimates, these 'implicit structures' are there in the ether where political doctrine meets educational policy, and 'always already' frame the debate (Aldridge 2015).

If my work has attempted to examine the origins and sources of these implicit structures and their epistemological makeup, we need, naturally, and not perchance, to remind ourselves that epistemology 
is itself political. As noted above, in the framings of Ball, Bourdieu and Foucault, struggle in the supremacy of ideas remains inimical to political and social life as it does to educational systems. Beyond the high theory, in educational terms there are no more powerful responses to the counter-balancing of disadvantage than those originating from Freire (2000) and the now expansive framings of critical theory as a critical pedagogy (Darder et al. 2017). Again, however, even across critical pedagogy, focus on economic inequality and social justice has seemingly obscured such scholars to the mechanisms of States and international security which maintain the status quo, a statement which find merely a nod of unsurprised acknowledgment from C. Wright Mills.

Evidence, specifically, of the politicization of religious education is, I think, convincing, but is part of a wider intellectual landscape, one drawn a century ago now by Weber and Schmitt. The drawing in of global security agendas into religious education serves to accentuate the notion that knowledge is in this case indeed power. This shifting of power, as we have noted, is as epistemological as it is political. And entirely central to what all variants of secularization theory have defined as a decline in and by a decline of religious authority. The appearance of security agendas across religion in education is an accentuation not a diminution of political authority over the religious, the theological. Do not religious educators in this sense, of a malaise, also share Weber's disenchantment in concrete ways, that is, to my view, in fact contribute to the processes of the secularization (or Weberian critical/intellectualization) itself.

\section{Disenchantment and a New Sociology of Elites}

New intellectual and political horizons come, then, to dominate the sociological landscape. Inevitably this involves transferences of authority and power, the creation of new elites. The intellectual milieu of Weber's sociology of disenchantment and Schmitt's political theology provide their own insights on this shifting moment in the history of ideas given socio-political form. In the loss of religious influence through the processes which Weber described, a new sociological of elites or sociology of the new elites, is de facto formed.

In its aetiology, in its genesis, the educational sociology and political theology has some conceptual linkages to the sociology of elites' theory. Further, elites' theory has potential explanatory frameworks to further understandings of these new epistemological and socio-political landscapes. Most directly, we see this in the same period as Weber and Schmitt, in the south of Europe, where another emergent justification of extreme State power was to be an anticipation of Fascism in Italy. For example, we read, though today we rarely do, Pareto (1991) The Rise and Fall of Elites, interestingly subtitled, An Application of Theoretical Sociology. There is also Mosca (1960) The Ruling Class (Albertoni and Goodrick 1987; Aron 1967; Hartmann 2007). Pareto, along with Mosca, was avowedly counter-Marxist in the interpretation of the right order of social relations. Contra eighteenth century models of democracy, they found acceptable expression not only for the sociology of elitism but a scholarly defence of dictatorship. Such philosophies of society thus found political expression as we know in autocracy, dictatorship, and destruction.

If Schmitt, Pareto and Mosca lost their academic respectability in the defeat of Nazism and Fascism, so they now see a revival via current intellectual trends in political theology as well as in the popularity of elites' theory itself. So, then, the sociological insights of these politically extreme scholars provided the groundwork for later sociologies of elitism and elite research methodologies (for example, Neal and McLaughlin 2009). Preeminent amongst these are Mills (2000) The Power Elite, Williams (2012) Researching Power, Elites and Leadership, Domhoff (2017) Studying the Power Elite. Thus, an emergent and significant literature is preoccupied with researching new forms of the elite and the powerful in the social and political sciences (Ball 2013; Ozga 2011; Walford 1994, 2011; Williams 2012). More than an outline of some points of interconnection between educational sociology and political theology would be required to advance further our appropriate methods empirically to study these areas of interest. The key questions, research questions as yet not properly addressed anywhere in the literature of educational sociological or policy sociology,, these questions centre, to my mind, around questions of 
power and authority in relation to the formation of religious curriculum policy, in ways which provide some specificity to the generalised but important emphasis placed upon decision-making in elites' theory as Abend has recently highlighted in a thought-provoking paper (Abend 2018). It would seem that Weber's disenchantment and Schmitt's political theology at the very least open up here as yet under-explored possibilities for a direction in the sociology of elites.

\section{Conclusions}

In one form or another, therefore, all literature on secularization relates to disenchantment, the removal that is of transcendent referents to a political or alternative source of epistemological, ideological or other intellectual power. With sufficient momentum, the idea or ideas, as Hegel, Marx and Weber too remind us, arises from and takes material form in the world of society. Disenchantment is both a removal, a deficit, and, when we re-read Weber's lecture, a replacement by something else. That something else has been detailed exhaustively in the political and social sciences. In education, there has been less critically observed. Indeed, many practitioners and researchers are themselves party to a collaboration of unintended (secularizing and securitizing) consequence. The processes and direction of this trajectory I have detailed extensively in other writings, in this current piece I have provided some bare outline of secularization and securitization being advanced through the vehicle of education, evidenced particularly transmogrification of secular outlooks and security goals to global curriculum policy for religion in education. Here, this securitization is the latest, and surprising, item in a long line of staging posts in the history of secularization.

It turns out that Milbank (1990) magisterial Theology and Social Theory may have been especially prescient in referring to a 'policing of the sublime'. This is what I term here a 'securitization of the sacred'. I suggest that this securitization of the sacred is most evidently observed through policy and practice in religion in education. It is, further, to me incontrovertible evidence that God is back not in the terms of religious authority but in other terms, not only of governments but of guns. Securitization is therefore one of the last staging posts of secularization.

For those with the imagination and independence of thought to look, the secularization and the securitization of the sacred are evident in policies for religion in education. In recent work I have shown in comparative detail the different forms this takes in the UK and the US. Indeed, in this work I argue that the very criticality (Weber's intellectualization) of religion in education-sustained over years in schools-is a contributory factor to declining patterns of religious belief and practice, the authority of religious life undermined consciously and unconsciously as Schmitt had identified by a progress shifting of the locus of power from theological to the political. Securitization of religion in education is not simply an aspect of the politicization of religion in education it is its natural consequence. Weber and Schmitt both saw this a century ago. It is the task of educational sociology and political theology today to extend exploration of this less examined terrain. It is my hypothesis that there, behind the policies, we will find evidence of one or more sources of what $C$. Wright Mills determined as the 'power elite'. These are the origins and ends of disenchantment.

Funding: The author gratefully acknowledges the support of the Arts and Humanities Research Council (AHRC) Political Theologies, Grant Reference AH/H008543 in contributing to the theoretical framing of this article.

Acknowledgments: The author is grateful for the invitation to be a keynote speaker at the British Sociological Association Sociology of Religion conference in July 2018 at the University of Strathclyde, and for constructive comments received which assisted in the formulation of this article; and the author acknowledges too comments by the anonymous peer reviewers.

Conflicts of Interest: The author declares no conflict of interest. 


\section{References}

Abend, Gabriel. 2018. Outline of a sociology of decisionism. British Journal of Sociology 69: 237-64. [CrossRef] [PubMed]

Albert, Mathias, and Barry Buzan. 2011. Securitization, sectors and functional differentiation. Security Dialogue 42: 413-25. [CrossRef]

Albertoni, Eltore A., and Paul Goodrick. 1987. Mosca and the Theory of Elitism. London: Routledge.

Aldridge, David. 2015. A Hermeneutics of Religious Education. London: Bloomsbury.

Alexander, James. 1994. Vilfredo Pareto: Sociologist and philosopher—Life, work and impact of the "Karl Marx of fascism". Journal of Historical Review 14: 10-18.

Arendt, Hannah. 2004. The Origins of Totalitarianism. New York: Schocken Books.

Aron, Raymond. 1967. Main Currents in Sociological Thought: Durkheim, Pareto, Weber. New York: Basic Book. Ball, Stephen J. 2013. Foucault, Power and Education. London: Routledge.

Bellah, Robert. 1967. Civil religion in America. Daedalus 96: 1-21.

Berger, Peter. 1967. The Sacred Canopy. New York: Doubleday.

Berger, Peter. 1970. A Rumor of Angels: Modern Society and the Rediscovery of the Supernatural. Garden City: Doubleday.

Berger, Peter, ed. 1999. The Desecularization of the World: Resurgent Religion and World Politics. Grand Rapids: Eerdmans.

Berlin, Isaiah. 2002. Two concepts of liberty. In Liberty. Edited by Henry Hardy. Oxford: Oxford University Press, pp. 166-217.

Bourdieu, Pierre. 1986. The forms of capital. In Handbook of Theory and Research for the Sociology of Education. Edited by J. Richardson. Westport: Greenwood.

Bruce, Steve. 2002. God Is Dead. Oxford: Blackwell.

Buzan, Barry, Ole Waever, and Jaap De Wilde. 1997. Security: A New Framework for Analysis. Boulder: Lynne Rienner Publishers Inc.

Carroll, A. J. 2009. The Importance of Protestantism in Max Weber's Theory of Secularization. European Journal of Sociology/Archives Européennes de Sociologie 50: 61-95. [CrossRef]

Casanova, Jose. 1994. Public Religions in the Modern World. Chicago: Chicago University Press.

Casanova, Jose. 2009. The secular and secularism. Social Research 76: 1049-66.

Chaves, Mark. 1994. Secularization as declining religious authority. Social Forces 72: 749-74. [CrossRef]

CoE. 2008. Living Together as Equals in Dignity. Strasbourg: Council of Europe.

Darder, Antonia, Marta P. Baltodano, and Rodolfo. D. Torres, eds. 2017. The Critical Pedagogy Reader. London: Routledge.

Davie, Grace, Peter Berger, and Effie Fokas. 2008. Religious America, Secular Europe? Aldershot: Ashgate.

Davis, Derek, and Elena Miroshnikova, eds. 2017. The Routledge International Handbook of Religious Education. London and New York: Routledge.

Davis, Creston, John Milbank, and Slavoj Zizek. 2005. Theology and the Political: The New Debate. Durham: Duke University Press.

De Vries, Hent, and Lawrence E. Sullivan, eds. 2006. Political Theologies: Public Religions in a Post-Secular World. New York: Fordham.

Domhoff, G. William, ed. 2017. Studying the Power Elite. London: Routledge.

Dunn Cavelty, Myriam, and Thierry Balzacq, eds. 2017. The Routledge Handbook of Security Studies. London: Routledge.

Durham, W. Cole. 2017. Introduction. In The Routledge International Handbook of Religious Education. Edited by D. H. Davis and E. Miroshnikova. London: Routledge.

EAS. 2015. European Agenda on Security. Brussels: European Commission, Available online: https://ec.europa.eu/ home-affairs/what-we-do/policies/european-agenda-security_en (accessed on 21 December 2018).

Emden, Christian. J. 2006. Carl Schmitt. Political Theology: Four Chapters on the Concept of Sovereignty. H-Net Reviews in the Humanities and the Social Sciences. Available online: https:/ / www.h-net.org/reviews/ showpdf.php?id=12384 (accessed on 21 December 2018).

Ferrari, Silvio. 2017. Religious education in the European Union. In The Routledge International Handbook of Religious Education. Edited by Derek. H. Davis and Elena. Miroshnikova. London: Routledge. 
Feuerbach, Ludwig. 1989. The Essence of Christianity. London: Prometheus.

Foucault, Michel. 1970. The Order of Things. London: Tavistock.

Foucault, Michel. 1972. The Archaeology of Knowledge. New York: Pantheon.

Foucault, Michel. 1977. Discipline and Punish. London: Allen Lane.

Foucault, Michel. 1980. Power/Knowledge: Selected Interviews and Other Writings 1972-1977. Brighton: Harvester.

Foucault, Michel. 2009. Security, Territory, Population. New York: Picador.

Foucault, Michel. 2010. The Birth of Biopolitics. New York: Picador.

Freire, Paulo. 2000. Pedagogy of the Oppressed. London: Bloomsbury.

Friedrich, Carl Joachim, and Zbigniew K. Brzezinski. 1967. Totalitarian Dictatorship and Autocracy. New York: Praeger.

Gadamer, Hans-Georg. 2004. Truth and Method. London and New York: Continuum.

Gearon, Liam. 2013. The Counter Terrorist Classroom: Religion, Education, and Security. Religious Education 108: 129-47. [CrossRef]

Gearon, Liam. 2017a. Secularisation and the Securitisation of the Sacred: A Response to Lewin's Framing of the Gearon-Jackson Debate. British Journal of Educational Studies 65: 469-80. [CrossRef]

Gearon, Liam. 2017b. Paradigm Shift in Religious Education: A Reply to Jackson, or Why Religious Education Goes to War. Journal of Beliefs and Values 39: 358-78. [CrossRef]

Gearon, Liam. 2017c. The Counter-Terrorist Campus: Securitisation Theory and University Securitisation-Three Models. Transformation in Higher Education 2. Available online: https://thejournal.org.za/index.php/ thejournal/article/view/13/51 (accessed on 21 December 2018).

Gearon, Liam. 2018. Terrorism and Counter-Terrorism Policy and Research in UK Universities (1997-2017): An Analytic-Structural Review of the Literature and Related Sources. Policy Reviews in Higher Education 2: 32-60. [CrossRef]

Gearon, Liam, and Joseph Prud'homme. 2018. State Religious Education and the State of the Religious Life. Eugene: Wipf and Stock.

Ghosh, Peter. 2014. Max Weber and "The Protestant Ethic": Twin Histories. Oxford: Oxford University Press.

Ghosh, Ratna, Ashley Manuel, W. Y. Alice Chan, Maihemuti Dilimulati, and Mehdi Babaei. 2016. Education and Security: A Global Literature Review on the Role of Education in Countering Violent Religious Extremism. London: Tony Blair Institute for Global Change, Available online: https:/ /institute.global/sites/default/files/inlinefiles/IGC_Education\%20and\%20Security.pdf (accessed on 21 December 2018).

Goldstein, Warren S. 1999. Patterns of secularisation and religious rationalization in Emile Durkheim and Max Weber. Implicit Religion 12: 135-63.

Goldstein, Warren S. 2009. Secularisation patterns in the old paradigm. Sociology of Religion 70: 157-78. [CrossRef] Gray, John. 2017. Black Mass: Apocalyptic Religion and the Death of Utopia. London: Penguin.

Habermas, Jurgen. 2006. Religion in the public sphere. European Journal of Philosophy 14: 1-25. [CrossRef]

Habermas, Jurgen. 2008. Notes on post secular society. New Perspectives Quarterly 25: 17-29. [CrossRef]

Habermas, Jurgen, and Joseph Ratzinger. 2007. The Dialectics of Secularization: On Reason and Religion. San Francisco: Ignatius Press.

Hartmann, Michael. 2007. The Sociology of Elites. New York: Routledge.

Hayek, Friedrich August. 2001. Roads to Serfdom. London: Routledge.

Haynes, Jeffrey, ed. 2008. The Handbook of Religion and Politics. London: Routledge.

Haynes, Jeffrey, ed. 2009. Religion and Politics. London: Routledge.

Hobsbawm, Eric. 1995. Age of Extremes. London: Abacus.

Hohendal, Peter. 2008. Political Theology Revisited. Available online: http://journals.oregondigital.org/ konturen/article/view/1266/1286 (accessed on 21 December 2018).

Hollerich, Michael. 2011. Carl Schmitt. In Scott and Cavanaugh Political Theology. Oxford: Wiley-Blackwell.

Hovey, Craig, and Elizabeth Phillips, eds. 2015. The Cambridge Companion to Christian Political Theology. Cambridge: Cambridge University Press.

Hughey, Michael W. 1979. The idea of secularization in the works of Max Weber: A theoretical outline. Qualitative Sociology 2: 85-111. [CrossRef]

Hunter-Henin, Myriam. 2012. Law, Religious Freedoms and Education in Europe. Farnham: Ashgate.

Huntington, Samuel. 2002. The Clash of Civilizations. New York: Simon \& Schuster. 
Huysmans, Jeff. 1998. Revisiting Copenhagen: Or, on the creative development of a security studies agenda in Europe. European Journal of International Relations 4: 479-505. [CrossRef]

Jackson, Robert. 1997. Religious Education: An Interpretive Approach. London: Hodder and Stoughton.

Jackson, Robert. 2011. Religion, education, dialogue and conflict: editorial introduction. British Journal of Religious Education 33: 105-9. [CrossRef]

Jackson, Robert. 2014. Signposts-Policy and Practice for Teaching about Religions and Non-Religious World Views in Intercultural Education. Strasbourg: Council of Europe.

Jackson, Robert. 2015. The politicization and securitization of religious education? A rejoinder. British Journal of Educational Studies 63: 345-366. [CrossRef]

Jackson, Robert, and Kevin O'Grady. 2007. Religious education in England: Social plurality, civil religion and religious education pedagogy. In Religion and Education in Europe: Developments, Contexts and Debates. Edited by Robert Jackson, Siebren Miedema, Wolfram Weisse and Jean-Paul Willaime. Münster: Waxmann, pp. 181-202.

Jackson, Robert, Siebren Miedema, Wolfram Weisse, and Jean-Paul Willaime. 2007. Religion and Education in Europe: Developments, Contexts and Debates. Münster and New York: Waxman.

Kahn, Paul. 2012. Political Theology: Four New Chapters on the Concept of Sovereignty. New York: Columbia University Press.

Kant, Immanuel. 1784. What Is Enlightenment. Available online: http:/ / www.columbia.edu/acis/ets/CCREAD/ etscc/kant.html (accessed on 21 December 2018).

Koskenniemi, Marti. 2006. International Law as Political Theology. Available online: https:/ forhistiur.de/media/ zeitschrift/0603koskenniemi.pdf (accessed on 21 December 2018).

Laustsen, Carsten Bagge, and Ole Wæver. 2000. In defence of religion: Sacred referent objects for securitization. Millennium: Journal for International Studies 29: 705-39. [CrossRef]

Lewin, David. 2016. Educational Philosophy for a Post-Secular Age. London: Routledge.

Lewin, David. 2017a. Who's afraid of secularization? Reframing the debate between Gearon and Jackson. British Journal of Educational Studies 64: 445-61. [CrossRef]

Lewin, David. 2017b. The hermeneutics of religious understanding in a postsecular age. Ethics and Education 12: 73-83. [CrossRef]

Maier, Hans, ed. 2004. Totalitarianism and Political Religions. London: Routledge, vol. I.

Maier, Hans, ed. 2007. Totalitarianism and Political Religions. London: Routledge, vol. III.

Maier, Hans, and Michael Schafer Schafer, eds. 2007. Totalitarianism and Political Religions. London: Routledge, vol. II.

Marx, Karl. 2009. A Contribution to the Critique of Hegel's Philosophy of Right. Available online: https: / / www.marxists.org/archive/marx/works/1843/critique-hpr/intro.htm (accessed on 21 December 2018).

Micklethwait, John, and Adrian Wooldridge. 2010. God Is Back: How the Global Rise of Faith is Changing the World. London: Penguin.

Milbank, John. 1990. Theology and Social Theory. Oxford: Blackwell.

Mills, C. Wright. 2000. The Power Elite. Oxford: Oxford University Press.

Mosca, Gaetano. 1960. The Ruling Class. Columbus: McGraw-Hill.

Neal, Sarah, and Eugene McLaughlin. 2009. Researching up? Interviews, emotionality and policy-making elites. Journal of Social Policy 38: 689-707. [CrossRef]

Newell, Ted. 2015. A review of On Holy Ground: the theory and practice of religious education. Religious Education 110: 235-38. [CrossRef]

OSCE. 2007. The Toledo Guiding Principles on Teaching about Religions and Beliefs in Public Schools. Warsaw: Organisation for Security and Co-operation in Europe, Office for Democratic Institutions and Human Rights, Available online: http:/ / www.osce.org/odihr/29154 (accessed on 21 December 2018).

Ozga, Jennifer. 2011. Researching the powerful: Seeking knowledge about policy. European Educational Research Journal 10: 218-24. [CrossRef]

Paine, Thomas. 2008. Rights of Man. Oxford: Oxford University Press.

Pals, Daniel L. 2014. Nine Theories of Religion. Oxford: Oxford University Press.

Pareto, Vilfredo. 1963. The Mind and Society: A Treatise on General Sociology. New York: Harcourt, Brace.

Pareto, Vilfredo. 1991. The Rise and Fall of Elites: An Application of Theoretical Sociology. Piscataway: Transaction. 
Pollack, Detlef. 2013. Secularization Oxford Bibliographies. Available online: http:/ /www.oxfordbibliographies. com/view/document/obo-9780199756384/obo-9780199756384-0073.xml (accessed on 21 December 2018).

Popper, Karl. 2011. The Open Society and Its Enemies. London: Routledge.

Rousseau, Jean-Jacques. 1968. The Social Contract. London: Penguin.

Schmitt, Carl. 2005. Political Theology: Four Chapters on the Concept of Sovereignty. Chicago: Chicago University Press. Schussler Fiorenza, Francis, Klaus Tanner, and Michael Welker, eds. 2013. Political Theology: Contemporary Challenges and Future Directions. Louisville: Westminster John Knox Press.

Scott, Pete, and William T. Cavanaugh, eds. 2011. The Blackwell Companion of Political Theology. Oxford: Wiley-Blackwell.

Seiple, Chris, Dennis R. Hooper, and Pauletta Otis, eds. 2011. Routledge Handbook of Religion and Security: Theory and Practice. London and New York: Routledge.

Stark, Rodney. 1999. Secularization, RIP. Sociology of Religion 60: 249-73. [CrossRef]

Talmon, Jacob. L. 1961. The Origins of Totalitarian Democracy. London: Mercury Books.

Taureck, Rita. 2006. Securitization Theory and Securitization Studies. Journal of International Relations and Development 9: 53-61. [CrossRef]

Taylor, Charles. 2007. A Secular Age. Cambridge: Harvard University Press.

UN. 2018. United Nations Human Rights Office of the High Commissioner Special Rapporteur on Freedom of Religion or Belief. Available online: http://www.ohchr.org/EN/Issues/FreedomReligion/Pages/ FreedomReligionIndex.aspx (accessed on 21 December 2018).

UNAoC. 2018. United Nations Alliance of Civilizations. Available online: https://www.unaoc.org/ (accessed on 21 December 2018).

UNESCO. 2006. Guidelines on Intercultural Education. Paris: UNESCO.

UNESCO. 2011. Contemporary Issues in Human Rights Education. Paris: UNESCO.

Van Munster, Rens. 2016. Securitization. Oxford Bibliographies. Available online: http:/ / oxfordindex.oup.com/ view/10.1093/obo/9780199743292-0091 (accessed on 21 December 2018).

Vattimo, Gianni. 2003. After onto-theology: Philosophy between science and religion. In Religion after Metaphysics. Edited by Mark A. Wrathall. Cambridge: Cambridge University Press, pp. 29-36.

Vinx, Lars. 2014. Carl Schmitt. Stanford Encyclopedia of Philosophy. Available online: https:/ / plato.stanford.edu/ entries/schmitt/ (accessed on 21 December 2018).

Voegelin, Eric. 1999. The Collected Works of Eric Voegelin, Volume 5: Modernity without Restraint: The Political Religions, The New Science of Politics and Science, Politics and Gnosticism. Edited by Manfred Henningsen. Columbia: University of Missouri.

Walford, Geoffrey, ed. 1994. Researching the Powerful in Education. London: UCL Press.

Walford, Geoffrey. 2011. Researching the Powerful. Available online: https://www.bera.ac.uk/wp-content/ uploads / 2014/03/Researching-the-Powerful.pdf?noredirect=1 (accessed on 21 December 2018).

Warner, R. Stephen. 1993. Work in progress toward a new paradigm for the sociological study of religion in the United States. American Journal of Sociology 98: 1044-93. [CrossRef]

Weber, Max. 1946. Science as a Vocation. In From Max Weber: Essays in Sociology. New York: Oxford University Press, pp. 129-56.

Weber, Max. 2015. Max Weber's 'Science as a Vocation'. Edited by Peter Lassman, Irving Velody and Herminio Martins. London: Routledge.

Weiner, Tim. 2012. Legacy of Ashes: The History of the CIA. London: Penguin.

Weisse, Wolfram. 2011. Reflections on the REDCo project. British Journal of Religious Education 33: 111-25. [CrossRef]

Willaime, Jean-aul. 2007. Different models for religion and education in Europe. In Religion and Education in Europe. Edited by Robert Jackson, S. Miedema and W. Weisse. New York: Waxmann.

Williams, Christopher. 2012. Researching Power, Elites and Leadership. London: SAGE.

Wyschogrod, Edith. 1990. Spirit in Ashes: Hegel, Heidegger, and Man-Made Mass Death. New Haven: Yale University Press.

(C) 2018 by the author. Licensee MDPI, Basel, Switzerland. This article is an open access article distributed under the terms and conditions of the Creative Commons Attribution (CC BY) license (http://creativecommons.org/licenses/by/4.0/). 